\title{
Identification of Artificial Recharge Sites in Manchi Basin, Eastern Rajasthan (India) Using Remote Sensing and GIS Techniques
}

\author{
Subah Rais, Akram Javed \\ Department of Geology, Aligarh Muslim University, Aligarh, India \\ Email: subah.raisgeo@gmail.com
}

Received 15 February 2014; revised 15 March 2014; accepted 30 March 2014

Copyright (C) 2014 by authors and Scientific Research Publishing Inc.

This work is licensed under the Creative Commons Attribution International License (CC BY). http://creativecommons.org/licenses/by/4.0/

(c) (i) Open Access

\begin{abstract}
The present study is an attempt to prepare a water resource development action plan for Manchi basin in Eastern Rajasthan (India) using remote sensing and GIS techniques. Satellite data have proven to be very useful for surface study, especially in the preparation of land use/land cover and geomorphological map. Morphometric parameters are analyzed to understand the basin characteristics and its influence on the water resources for instance bifurcation ratio indicates high surface run off and low recharge in SB-I, IV, V. Low drainage density ranges from 2.41 (SB-IV) to $2.99(\mathrm{SB}-\mathrm{V}) \mathrm{km} / \mathrm{km}^{2}$, with an average of $2.72 \mathrm{~km} / \mathrm{km}^{2}$ showing permeable strata, dense vegetation and low relief. Analysis of shape parameters i.e. elongation ratio and circularity ratio suggest that Manchi basin is elongated in shape. Whereas, slope, geology and geomorphological mapping is done to demarcate groundwater potential zones for future exploration in the study area. Slope is inversely proportional to infiltration. Therefore, sub-basin areas having gentle slope permits less runoff and more infiltration as in alluvial plains and vice versa where hills and ridges are present. The integrated study helps in designing suitable sites for constructing water harvesting structures. Check dams, percolation tanks and nala bund are proposed at 1st, 2 nd or 3rd drainage orders at SB-I and SB-IV with ravenous land (open scrub), uncultivated land, open forest \& exposed rock present. Nala bund \& check dam are proposed at SB-II \& SB-V whereas, at SB-III check dams \& percolation tanks are proposed so as to conserve the natural resources present in the basin. Finally, the best feasible water harvesting structures have been proposed within the sub-basins area using remote sensing and GIS techniques.
\end{abstract}

\section{Keywords}

Morphometric Analysis, DEM, Hydrogeomorphology, Remote Sensing, GIS

How to cite this paper: Rais, S. and Javed, A. (2014) Identification of Artificial Recharge Sites in Manchi Basin, Eastern Rajasthan (India) Using Remote Sensing and GIS Techniques. Journal of Geographic Information System, 6, 162-175. 


\section{Introduction}

Drainage basins are the fundamental units to understand geometric characteristics of fluvial landscape, such as topology of stream networks, quantitative description of drainage texture, pattern, shape and relief characteristics [1] [2]. Morphometric analysis is an important technique to evaluate and understand the behaviour of hydrological system. It provides quantitative specification of basin geometry to understand initial slope or inconsistencies in rock hardness, structural controls, recent diastrophism, geological and geomorphic history of drainage basin [3]. Morphometric parameters along with physical aspects such as slope, lithology, elevation, land use/land cover etc. are used to identify suitable sites and structures for groundwater recharge, which are useful in water resources development plan.

In the recent past several studies have been carried out based on GIS and remote sensing applications in delineating groundwater potential zones so as to formulate water resource development plan [4]-[8]. Few researchers [9] [10] have used varying number of thematic layers, such as geology, geomorphology, drainage density, slope, aquifer transmissivity, water table fluctuations or depth to groundwater level, lineament density etc., for identification of artificial recharge sites. Others have attempted to select suitable sites for artificial recharge as well as to suggest site specific recharge structures [11] [12]. Remote sensing and GIS have been employed in the present study superimposing thematic maps like Drainage, Geology, Geomorphology, Digital Elevation Model (DEM) and Slope to extract useful information so, as to formulate a water resource development plan for the Manchi Basin, Eastern Rajasthan, India.

\section{Study Area}

Manchi basin in Eastern Rajasthan (India) spreads over an area of $235.64 \mathrm{~km}^{2}$, bounded by N latitudes $26^{\circ} 25^{\prime}$ to $26^{\circ} 45^{\prime}$ and E longitudes $77^{\circ} 00^{\prime}$ to $77^{\circ} 15^{\prime}$ (Figure 1) falls in Karauli district. The maximum and minimum elevation encountered in the basin is $367 \mathrm{~m}$ and $231 \mathrm{~m}$ above mean sea level respectively. The Digital Elevation Model represents higher elevation range 341 - $367 \mathrm{~m}$ above mean sea level in the form of Hills and ridges in the South-West, North, and North-eastern part of the basin. Lower elevation range of 259 - 285 m above mean sea level is represented by alluvium. Slope ranges from $0^{\circ}$ to $28^{\circ}$, Gentle slope $\left(0^{\circ}\right.$ to $\left.7^{\circ}\right)$ is reported from major part of the area in north and south, moderate to steep $\left(15^{\circ}-21^{\circ}\right)$ in north, north-west, south and central part. Whereas, very steep $\left(22^{\circ}-28^{\circ}\right)$ in southern part of the basin. The area represents semi-arid climatic regime with low and erratic rainfall. Climate data record of 1977-2007 period suggests that the average annual rainfall has declined by $63.92 \mathrm{~mm}$ affecting surface as well as ground water resources.

Drainage pattern developed within the study area is dendritic, however locally trellis and radial is also observed. The plains are fertile with light sandy soil. Grayish brown to dark grayish brown, clay loam to clay soils developed from hills. The soil is generally alluvial in nature which is prone to water logging. Major crops grown in the district are bajra, wheat, mustard, rapeseed, sesame seed, maize and gram.

\section{Data Used and Methodology}

Survey of India toposheet (SOI) nos. 54F/2 and 54F/3 on 1:50,000 scale were used for preparation of Base map and for delineating basin boundary. False Colour Composite (FCC) of Indian Remote Sensing Satellite (IRS P6) LISS III of 11th May, 2012 having band combination 234 and spatial resolution of 23.5 m was utilized for thematic mapping. The image was bought from National Remote Sensing Centre (NRSC) and its preprocessing was done from there. Advanced Space borne Thermal Emission Radiometer (ASTER) data of 30 m resolution was downloaded from the website (http://www.gdem.aster.erdac.or.jp/search.jsp) and was subsequently utilized for preparation of Digital Elevation Model (DEM) and Slope maps. District resource map published by Geological Survey of India was used for extracting lithological units of Manchi basin. Climate data for 30 years (1997-2007) related to rainfall and temperature was obtained from India Meteorological Department (IMD), Pune.

Besides, secondary information/data were collected from various sources and utilized wherever required, District Statistical handbook, 2005 and other information from government and non-government sources were also consulted. Limited ground truth verification was also carried out in key areas to ascertain the veracity of satellite data, and as an input to the final analysis.

The study involves various steps, the first step was to prepare a base map using Survey of India toposheet. Drainage network was initially derived from SOI toposheet on a transparency and later updated from IRS P6 


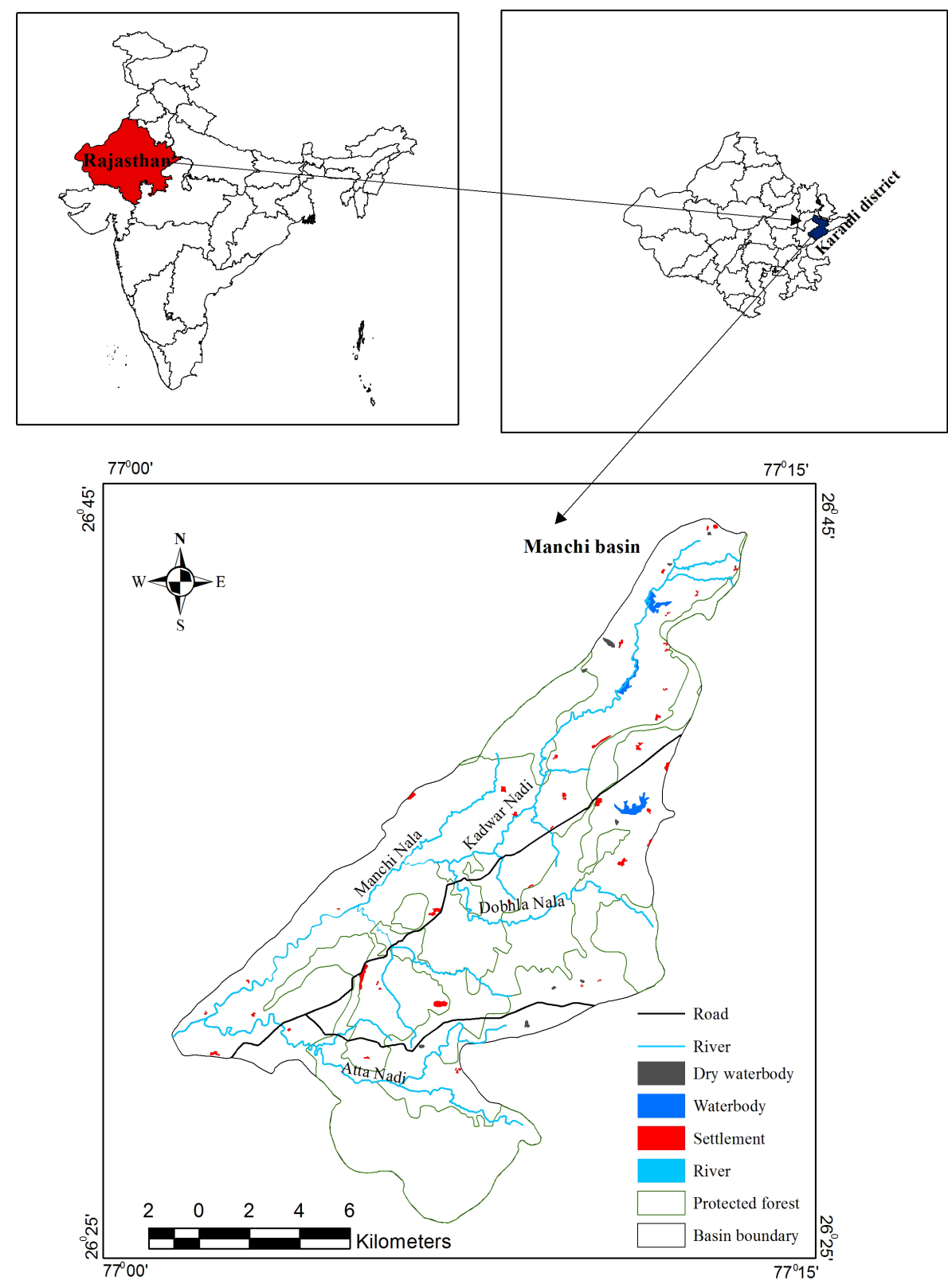

Figure 1. Location map of the study area.

LISS-III FCC. Basin boundary was demarcated based on drainage lines considering slope, contours, elevation, spot height etc. Following the same procedure sub-basin boundaries were also demarcated. The drainage map was scanned georeferenced and subsequently digitized for creation of drainage layers as line coverage, giving unique id for each order of stream. Based on the drainage characteristics, the whole basin was divided into five sub basins i.e. SB-I to SB-V. Various morphometric parameters (linear, areal and relief) were computed for each sub-basin using standard methods and formulae.

Geological map showing lithounits was derived from District Resource map, on a tracing film and later digitized in GIS environment using Arc GIS10. Whereas, IRS P6 LISS-III (FCC) of 11th May 2012 was utilized for preparation of land use/land cover map. Polygon topology was built for each lithounit and land use/land cover categories, after assigning unique ids for every polygon feature using Arc GIS, the coverage was edited and cleaned before further analysis.

ASTER data was utilized for preparation of Digital Elevation Model (DEM) (Figure 2), using SAGA software. 


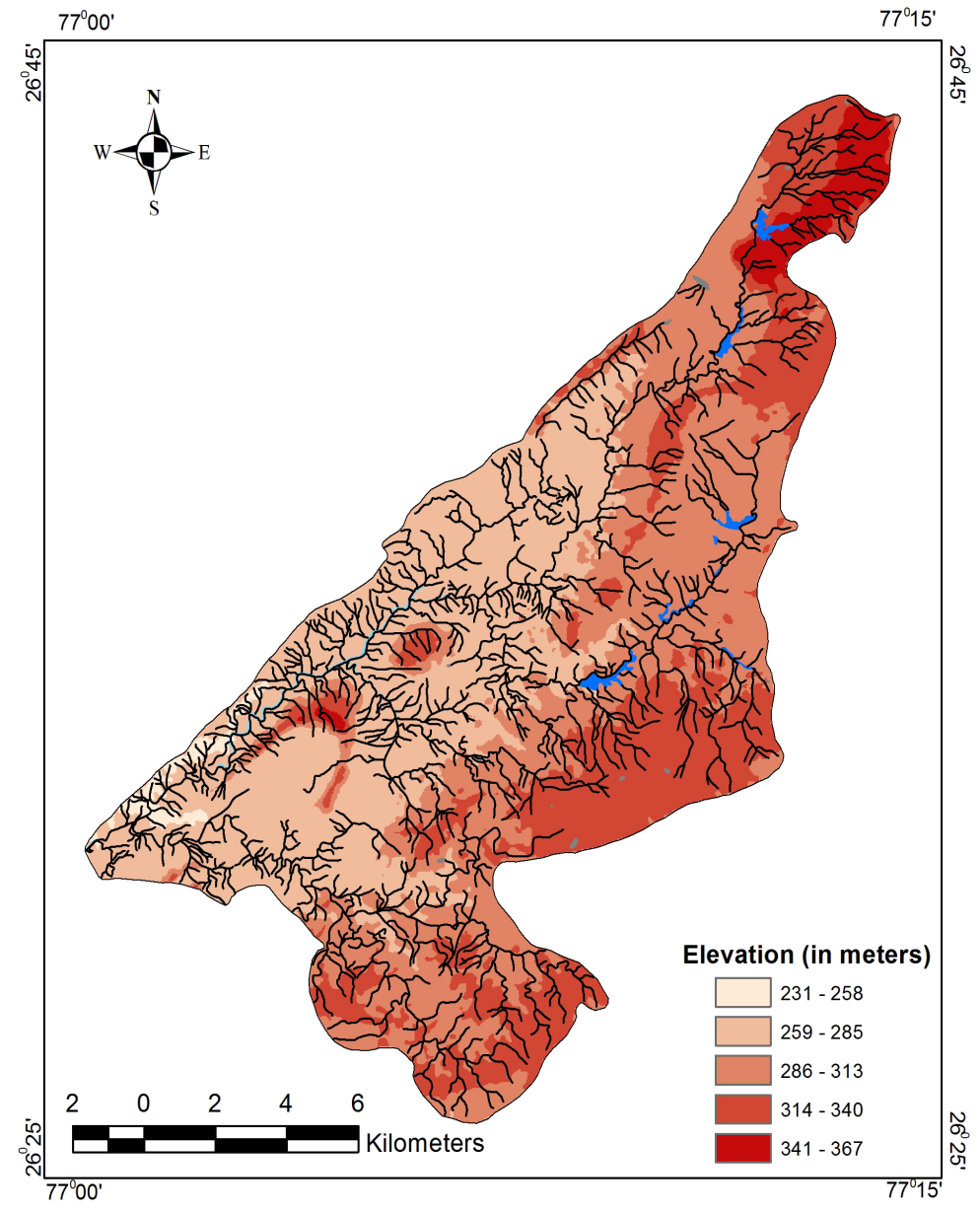

Figure 2. Drainage superimposed on digital elevation model (DEM).

Thus, taking the DEM as input Slope map was created in ARC-GIS software, and it was categorized into four classes as Gentle $\left(0^{\circ}-7^{\circ}\right)$, Moderate $\left(8^{\circ}-14^{\circ}\right)$, Steep $\left(15^{\circ}-21^{\circ}\right)$, Very steep $\left(22^{\circ}-28^{\circ}\right)$.

\section{Results and Discussion}

\subsection{Morphometric Analysis}

Morphometry is the measurement and mathematical analysis of the configuration of the Earth's surface, shape and dimensions of its landforms [13]. Drainage analysis based on morphometric parameters is very important for watershed planning since it gives an idea about the basin characteristics in terms of slope, topography, soil condition, runoff characteristics, surface water potential etc. [14]. For developing water resources of a basin terrain parameters like topography, lithology, hydrology, basin characteristics etc. are required to be analysed in GIS domain to as to arrive at integrated analysis. The inter-relationship between these parameters play a significant role in demarcating promising areas of water resources development. Morphological parameters are considered as guiding tools for identifying the necessity of selecting a particular type of soil and water conservation structure in sub-basins. Morphometric parameters utilized for the present study are discussed as under.

\subsubsection{Bifurcation Ratio (Rb)}

Bifurcation Ratio $(\mathrm{Rb})$ is the ratio of the number of streams of a given order to the number of streams of the next higher order [15]. Higher values of Rbm for a sub-watershed indicate high runoff, low recharge, and mature topography. Thus, high value of bifurcation ratio for sub-basins I, IV, V clearly indicates high surface run off and low recharge (Table 1). 
Table 1. Computational results of linear Morphometric parameter of sub-basins of the Manchi basin.

\begin{tabular}{|c|c|c|c|c|c|c|c|c|c|c|c|c|}
\hline \multirow{2}{*}{ Sub-basins } & \multirow{2}{*}{ Basin length (km) } & \multicolumn{6}{|c|}{ No. of streams of different order } & \multicolumn{5}{|c|}{ Bifurcation ratio $(\mathbf{R b})$} \\
\hline & & 1 & 2 & 3 & 4 & 5 & $\Sigma \mathrm{Nu}$ & $1 / 2$ & $2 / 3$ & $3 / 4$ & $4 / 5$ & Mean Rb \\
\hline $\mathbf{I}$ & 14.14 & 165 & 36 & 8 & 1 & - & 210 & 4.58 & 4.5 & 8 & - & 5.69 \\
\hline II & 9.23 & 79 & 16 & 3 & 1 & - & 99 & 4.93 & 5.33 & 3 & - & 4.42 \\
\hline III & 13.14 & 59 & 16 & 4 & 1 & - & 80 & 3.69 & 4 & 4 & - & 3.90 \\
\hline IV & 16.47 & 129 & 40 & 10 & 1 & - & 180 & 3.23 & 4 & 10 & - & 5.74 \\
\hline $\mathbf{V}$ & 13.90 & 263 & 64 & 3 & 1 & 1 & 332 & 4.11 & 21.33 & 3 & 1 & 7.36 \\
\hline Average & 13.38 & 139 & 34.4 & 5.6 & 1 & 0.2 & 180.2 & 4.11 & 7.83 & 5.6 & 0.2 & 4.44 \\
\hline Manchi Basin & 30.39 & 695 & 172 & 28 & 5 & 1 & 901 & 4.04 & 6.14 & 5.6 & 5 & 5.20 \\
\hline
\end{tabular}

\subsubsection{Drainage Density (Dd)}

It is the total length of streams of all orders divided by the area of drainage basin and indicates closeness of spacing of channels [16] [17]. In the study area low drainage density ranges from 2.41 (SB-IV) to 2.99 (SB-V) $\mathrm{km} / \mathrm{km}^{2}$, with an average of $2.72 \mathrm{~km} / \mathrm{km}^{2}$. This signifies that the strata is permeable, with dense vegetation and low relief. Present study even shows that the area with moderate to high drainage density is poor in case of ground water prospect thus; most of the water is lost as surface runoff leaving behind less infiltration. On the contrary low drainage density areas permit more infiltration and recharge to the groundwater and therefore act as good source for groundwater recharge (Table 2).

\subsubsection{Circularity Ratio (Rc)}

It is the ratio of area of basin to the area of circle having same circumference as the perimeter of the basin [18]. Values $>0.5$ suggest that the basin is more or less circular in shape and the quantity of discharge is comparatively less in sub-basins with lower Rc values. In the study areas the values of Rc ranging from 0.25 (SB-III, SB-IV, $\mathrm{SB}-\mathrm{V}$ ) to 0.38 (SB-I, SB-II) suggests that the sub-basins possess low discharge.

\subsubsection{Elongation Ratio (Re)}

Elongation ratio is the ratio between the diameter of the circle of the same area as the drainage basin (A) and the maximum length (L) of the basin [15]. Higher values indicate active denudational processes with high infiltration capacity and low run-off. Whereas, lower values indicate higher elevation of the basin susceptible to high headward erosion along tectonic lineaments [1] [19]. Values close to 1.0 are typical of regions of very low relief, whereas those in the range of 0.6 - 0.8 are generally associated with high relief and steep ground slope [15]. Re values in Manchi basin range from 0.37 (SB-III) to 0.7 (SB-V) suggests that the sub basins are less elongated, and possess low to moderate infiltration.

\subsubsection{Relief Ratio (Rh)}

The ratio of maximum relief to horizontal distance along the longest dimension of the basin parallel to the principal drainage line is termed as relief ratio [15]. It normally increases with decreasing drainage area and size of sub-watersheds of a drainage basin [20]. The Rh of the Manchi basin is 0.005, (Table 2) whereas Rh value of sub-basins varies from 0.004 (SB-III) to 0.01 (SB-II).

\subsubsection{Ruggedness Number (Rn)}

Ruggedness number is the product of maximum basin relief and drainage density where both terms are in same units [3]. It indicates the structural complexity of the terrain [15]. The Manchi basin with Rn value of 0.38 indicates moderate basin relief (136 m).

\subsection{Geology and Geohydrology}

The rock types exposed in the Manchi basin belong to Vindhyan Supergroup of Middle to Upper Proterozoic 
age representing four lithounits i.e. Alluvium, Sandstone, Limestone and Shale (Figure 3). Upper Bhandar (maihar) and lower Bhandar (bundi hill) sandstone, Sirbu shale and limestone belongs to Bhandari Group represented by soft, laminated, fissile rock and thin to thickly bedded spotted rock. Alluvium occupies the major portion of the study area, in the north, north-west, central and south-west parts of the basin. These alluvial plains

Table 2. Morphometric parameters of Manchi basin.

\begin{tabular}{cccccccccc}
\hline Sub-basins & Area $\left(\mathbf{k m}^{2}\right)$ & $\mathbf{P}(\mathbf{k m})$ & $\mathbf{D d}\left(\mathbf{k m} / \mathbf{k m}^{2}\right)$ & $\mathbf{R b m}$ & $\mathbf{R e}$ & $\mathbf{R c}$ & $\mathbf{R n}$ & Basin relief $(\mathbf{R})(\mathbf{k m})$ & Relief ratio $(\mathbf{R h})$ \\
\hline I & 57.84 & 45.93 & 2.78 & 5.69 & 0.60 & 0.38 & 0.23 & 0.083 & 0.006 \\
II & 26.36 & 28.62 & 2.80 & 4.42 & 0.61 & 0.38 & 0.26 & 0.093 & 0.01 \\
III & 19.2 & 30.30 & 2.61 & 3.90 & 0.37 & 0.25 & 0.15 & 0.059 & 0.004 \\
IV & 54.05 & 46.83 & 2.41 & 5.74 & 0.50 & 0.25 & 0.24 & 0.101 & 0.006 \\
V & 78.18 & 71.10 & 2.99 & 7.36 & 0.70 & 0.25 & 0.37 & 0.124 & 0.005 \\
Manchi basin & 235.64 & 89.37 & 2.75 & 5.20 & 0.09 & 0.25 & 0.38 & 0.136 & 0.005 \\
\hline
\end{tabular}

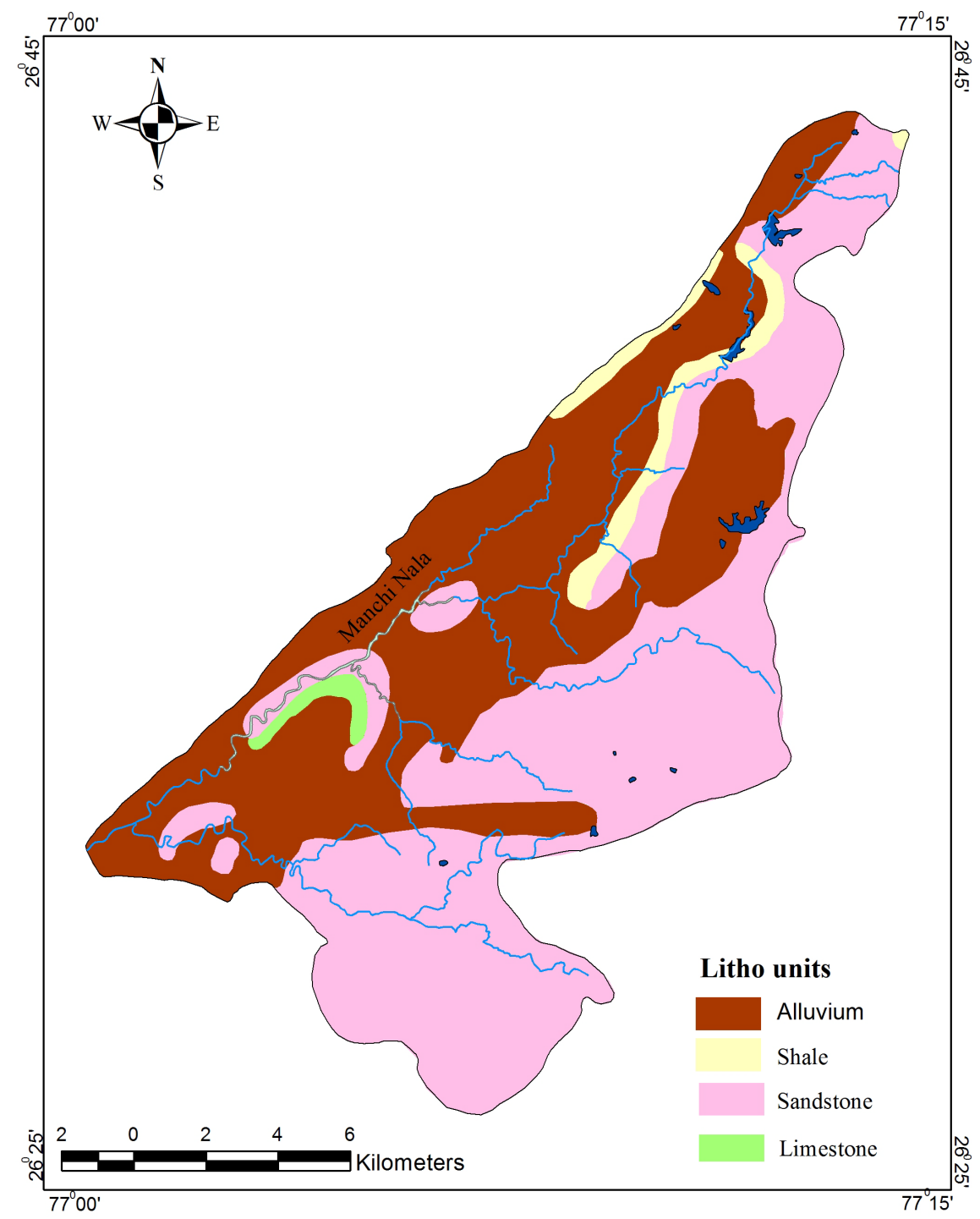

Figure 3. Geological map of the study area. 
consist mainly of coarse to fine sand, sand loam, kankar and silt with occasional clay bands. Sand stone is red in colour, fine to medium in grain size, compact, moderately hard and bedded in nature. It occupies the other major portion in Manchi basin i.e. in north, north east, south and south-western part. Sirbu shale is prominent in hilly tracts of Karauli district and is found to be approximately around 150 - $180 \mathrm{~m}$ thick in the north and northwestern parts of the basin. The limestone is greyish or yellowish in colour and is associated with chert bands at places and is present in south-western as small unit.

Geohydrologically, Manchi basin has been divided into two units i.e consolidated fissured formations and hilly area. Major part of Manchi basin is occupied by consolidated fissured formation, with hills traversing at some places. Ground water potential is between 1 and 5 LPS (litres per seconds) in consolidated fissured formations whereas it's below 1 LPS in hilly area.

\subsection{Slope}

Slope analysis is an important parameter in geomorphic studies. The slope in Manchi basin varies from $0^{\circ}$ to $28^{\circ}$ and classified into four classes as Gentle $\left(0^{\circ}-7^{\circ}\right)$, Moderate $\left(8^{\circ}-14^{\circ}\right)$, Steep $\left(15^{\circ}-21^{\circ}\right)$ and Very steep $\left(22^{\circ}\right.$ $28^{\circ}$ ) (Figure 4). Slope plays a very important role in determining infiltration vs. runoff relation. Infiltration is inversely related to slope i.e. gentler is the slope, higher is infiltration and less is runoff and vice-versa. The slope elements, in turn are controlled by the climatomorphogenic processes in the area having the rock of varying resistance. An understanding of slope distribution is essential as a slope map provides data for planning, settlement, mechanization of agriculture, deforestation, planning of engineering structures, morpho conservation

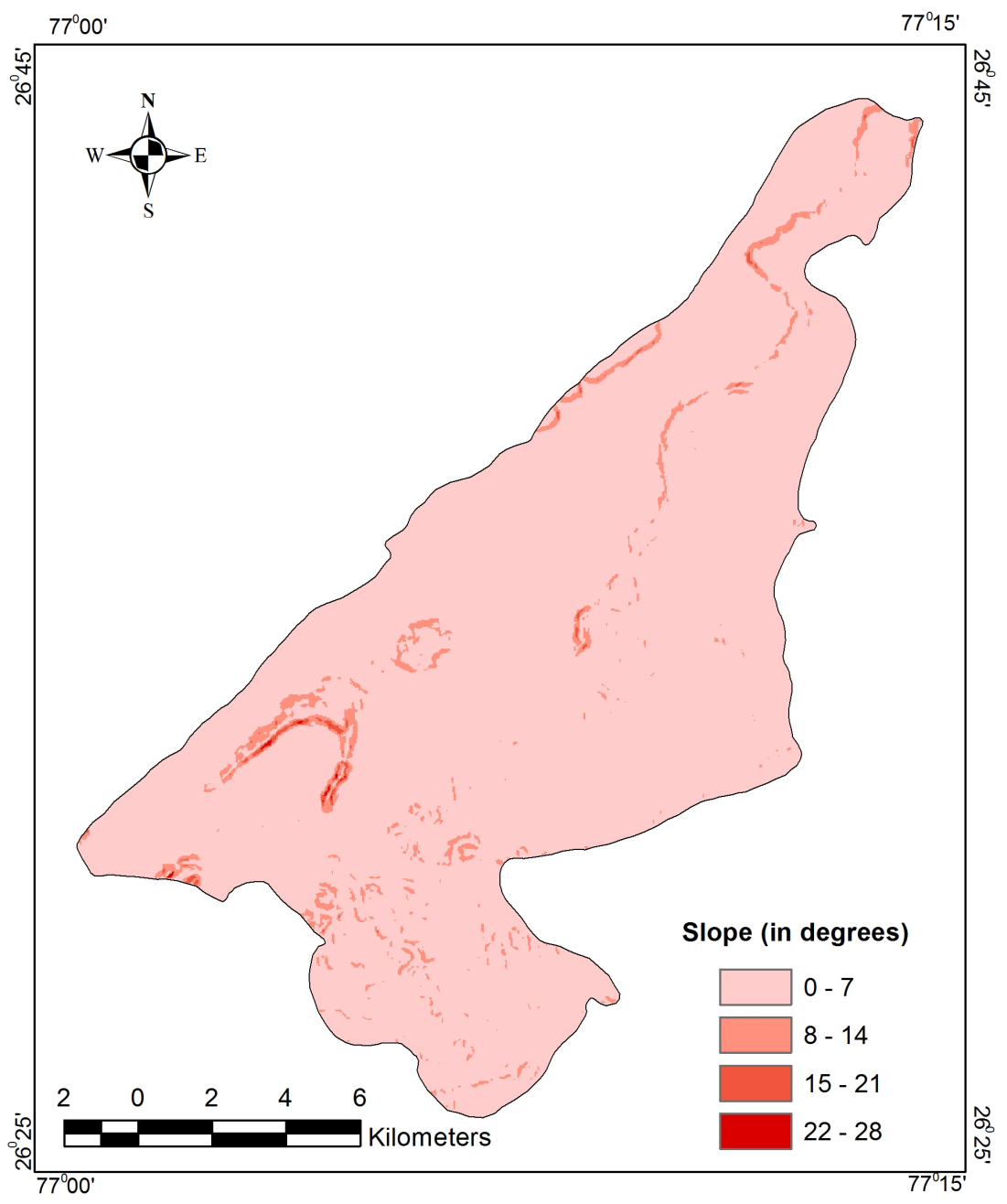

Figure 4. Slope map of the study area. 
practices etc. [21]. Slope map was generated from DEM derived from ASTER data using Arc-GIS. Aspect grid is identified as "the down-slope direction of the maximum rate of change in value from each to its neighbours" [22].

\subsection{Hydrogeomorphology}

The following hydrogeomorphic units are identified and delineated on the satellite data using photographic elements, field knowledge and topographic features (Figure 5) (Table 3, Table 4).

\subsubsection{Alluvial Plains}

Tone is bright red for cropland. Smooth texture, irregular shape, curvilinear outlines, contiguous pattern. Major portion covered by alluvial plains is $49.70 \%$ (SB-IV). The relief is defined by gently sloping surface at an elevation of 259 - $289 \mathrm{~m}$ above mean sea level. It normally acts as the discharge zones. The groundwater prospect in this unit is moderate to good.

\subsubsection{Ravenous/Gullied Land}

Dark brown tone, uneven and rough texture and moderate to high drainage density, with linear to dendritic drainage pattern. Land cover present is open scrub. Ravenous land covers $27.91 \%$ area and is estimated to cover a

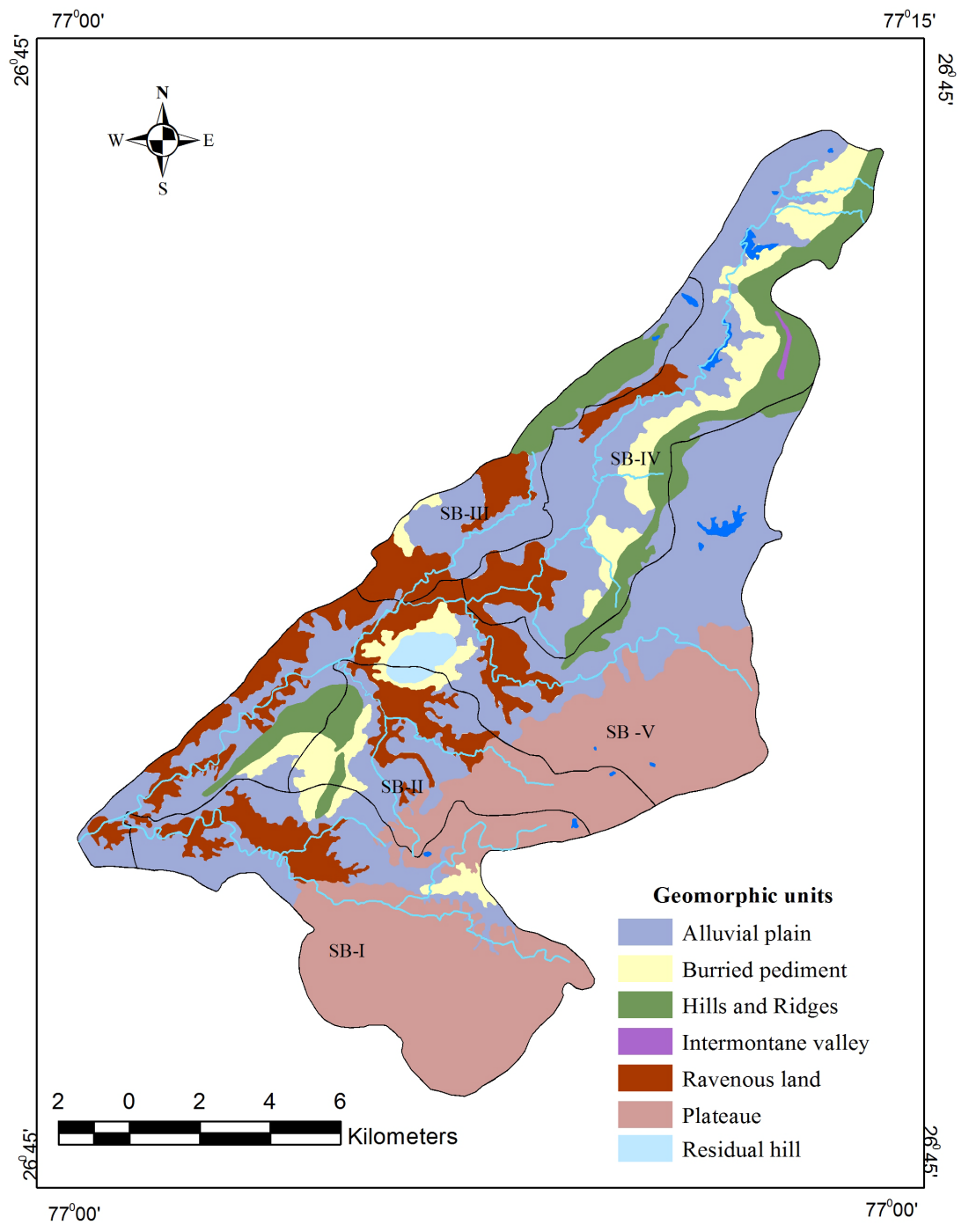

Figure 5. Hydrogeomorphic map of the study area. 
Table 3. Groundwater prospect at sub-basin level.

\begin{tabular}{ccccccc}
\hline Geomorphic units & Water prospect & SB-I (\%) & SB-II (\%) & SB-III (\%) & SB-IV (\%) & SB-V (\%) \\
\hline Alluvial plain & Good-moderate & 22.28 & 26.73 & 48 & 49.70 & 43.27 \\
Ravenous land & Moderate-poor & 9.73 & 19.52 & 27.91 & 9.32 & 19.47 \\
Buried pediment & Good-moderate & 3.06 & 9.91 & 2.85 & 19.30 & 3.52 \\
Hills and ridges & Poor-very poor & 0.59 & 5.21 & 21.23 & 21.31 & 5.82 \\
Plateaue & Moderate-poor & 64.31 & 36.82 & - & - & 25.99 \\
Intermontane valley & Moderate-poor & - & - & - & -47 & - \\
Residual hill & Poor-very poor & - & 1.82 & - & - & 1.94 \\
\hline
\end{tabular}

Table 4. Hydrogeomorphic units, their characteristics \& results of GIS analysis showing prospects.

\begin{tabular}{|c|c|c|c|c|c|c|}
\hline $\begin{array}{l}\text { Hydrogeomor-phic } \\
\text { units }\end{array}$ & $\begin{array}{c}\text { Description } \\
\text { (Field observation) }\end{array}$ & Image characteristics & Lithounits & $\begin{array}{c}\text { Slope } \\
\text { (degrees) }\end{array}$ & $\begin{array}{l}\text { Drainage } \\
\text { density }\end{array}$ & $\begin{array}{c}\text { Groundwater } \\
\text { potential/ } \\
\text { prospects }\end{array}$ \\
\hline Alluvial plain & $\begin{array}{l}\text { Gently sloping tract produced } \\
\text { by deposition of alluvial } \\
\text { material consisting of gravel, } \\
\text { sand, silt and clay of varying } \\
\text { lithology. }\end{array}$ & $\begin{array}{l}\text { Tone: Bright red for } \\
\text { cropland. Smooth Texture, } \\
\text { irregular shape, curvilinear } \\
\text { outlines, contiguous pattern. }\end{array}$ & Alluvium & $\begin{array}{l}\text { Gentle } \\
(0-7)\end{array}$ & Low & $\begin{array}{l}\text { Good to } \\
\text { moderate }\end{array}$ \\
\hline $\begin{array}{l}\text { Ravenous/Gullied } \\
\text { land }\end{array}$ & $\begin{array}{l}\text { Ravine is usually associated } \\
\text { not with an isolated gully but } \\
\text { an intricate network of gullies } \\
\text { formed generally in deep } \\
\text { alluvium and entering a nearby } \\
\text { river, flowing much lower than } \\
\text { the surrounding tablelands. }\end{array}$ & $\begin{array}{l}\text { Tone: dark brown tone, } \\
\text { uneven nd rough texture, } \\
\text { and moderate to high } \\
\text { drainage density, with } \\
\text { linear to dendritic } \\
\text { drainage pattern. }\end{array}$ & Alluvium & $\begin{array}{l}\text { Gentle } \\
(0-7)\end{array}$ & $\begin{array}{l}\text { Moderate- } \\
\text { high }\end{array}$ & $\begin{array}{l}\text { Moderate } \\
\text { to poor }\end{array}$ \\
\hline Buried pediment & $\begin{array}{l}\text { Unconsolidated alluvial } \\
\text { materials fill irregularities on } \\
\text { the sandstone surfaces. Mostly } \\
\text { vegetated or cultivated lying } \\
\text { at foot hills. }\end{array}$ & $\begin{array}{l}\text { Tone: light green, fine } \\
\text { texture, irregular shape } \\
\text { and elongated, contiguous } \\
\text { pattern }\end{array}$ & Alluvium & $\begin{array}{l}\text { Gentle- } \\
\text { moderate } \\
(8-14)\end{array}$ & $\begin{array}{l}\text { Low- } \\
\text { moderate }\end{array}$ & $\begin{array}{l}\text { Good to } \\
\text { moderate }\end{array}$ \\
\hline Hills and ridges & $\begin{array}{l}\text { Acts as barrier as well as } \\
\text { carrier for ground-water } \\
\text { flow represents areas of high } \\
\text { runoff. This unit represents } \\
\text { Vindhyan sandstone. }\end{array}$ & $\begin{array}{l}\text { Tone: green to dark green, } \\
\text { Coarse texture, shape linear, } \\
\text { contiguous pattern. } \\
\text { Development of 1st order } \\
\text { drainage. }\end{array}$ & Sandstone & $\begin{array}{l}\text { Moderate- } \\
\text { Steep } \\
(15-21)\end{array}$ & Low & $\begin{array}{l}\text { Very poor } \\
\text { to poor }\end{array}$ \\
\hline Plateau & $\begin{array}{l}\text { Flat topped and arcuate, } \\
\text { showing definite trends, } \\
\text { scanty vegetation. } \\
\text { Weathering is also found at } \\
\text { some places. Quarrying } \\
\text { activity at few places. }\end{array}$ & $\begin{array}{l}\text { Tone: dark green for rock } \\
\text { exposure to white for rock } \\
\text { quarrying, coarse texture, } \\
\text { irregular, dominated by } \\
\text { linear eatures. Sparse or } \\
\text { no vegetation, presence of } \\
\text { quarrying activity. }\end{array}$ & Sandstone & $\begin{array}{l}\text { Moderate- } \\
\text { Steep } \\
(15-21)\end{array}$ & $\begin{array}{l}\text { Moderate- } \\
\text { high }\end{array}$ & $\begin{array}{l}\text { Moderate } \\
\text { to poor }\end{array}$ \\
\hline Intermontane valley & $\begin{array}{l}\text { Depression between the } \\
\text { mountains, generally } \\
\text { narrow and linear, filled with } \\
\text { colluvial and fluvial deposits } \\
\text { of varying grain size mostly } \\
\text { sand, silt and clay. }\end{array}$ & $\begin{array}{l}\text { Tone: light grey, coarse } \\
\text { texture, irregular shape, } \\
\text { linear and contiguous } \\
\text { pattern, sub parallel } \\
\text { drainage. }\end{array}$ & Sandstone & $\begin{array}{l}\text { Gentle } \\
(0-7)\end{array}$ & $\begin{array}{l}\text { Low- } \\
\text { moderate }\end{array}$ & $\begin{array}{l}\text { Moderate } \\
\text { to poor }\end{array}$ \\
\hline Residual hill & $\begin{array}{l}\text { It represents Vindhyan } \\
\text { sandstone, act as runoff } \\
\text { zone. }\end{array}$ & $\begin{array}{l}\text { Tone: light greyish to } \\
\text { greenish for rock } \\
\text { exposures. Coarse texture, } \\
\text { shape and size-irregular } \\
\text { and rounded, contiguous } \\
\text { pattern. Drainage is parallel. }\end{array}$ & Sandstone & $\begin{array}{l}\text { Moderate- } \\
\text { steep } \\
(15-21)\end{array}$ & Gentle & $\begin{array}{l}\text { Very poor } \\
\text { to poor }\end{array}$ \\
\hline
\end{tabular}


major part in SB-III. It is found at gentle slope $\left(0^{\circ}\right.$ to $\left.7^{\circ}\right)$ at an elevation of 259 - $289 \mathrm{~m}$ above (MSL). In this unit, groundwater prospect is poor to moderate.

\subsubsection{Buried Pediments}

They are reported at the base of the hills/ridges and are identified by light green tone with fine texture, irregular shape and elongated, contiguous pattern. This geomorphic unit is found almost in the entire sub basin covering a total area of $38.64 \mathrm{~km}^{2}$ of which $19.30 \%$ is found in SB-IV. Buried pediment is moderate to good in respect of ground water prospect.

\subsubsection{Hills and Ridges}

Green to dark green tone, coarse texture, shape is linear, contiguous pattern. Development of 1st order drainage. The basin covers a total area of about $54.16 \mathrm{~km}^{2}$ under hills and ridges, out of which, SB-IV covers a major part of it i.e. $21.31 \%$. Very poor to poor in respect of ground water prospects and act as run off zone. It is found at steeper slope at quite higher elevation.

\subsubsection{Plateau}

Dark green for rock exposure to white for rock quarrying, coarse texture, irregular, dominated by linear features. Sparse or no vegetation, presence of quarrying activity. Total areal extent of this unit is estimated to be 127.12 $\mathrm{km}^{2}$, of which $64.31 \%$ is found in SB-I. This geomorphic unit is considered poor to moderate for ground water prospect.

\subsubsection{Intermontane Valley}

Light grey tone, coarse texture, irregular shape, linear and contiguous pattern, sub parallel drainage. This unit is around $0.47 \mathrm{~km}^{2}$ in area and is found to be $0.47 \%$ in SB-IV. Good to Moderate in case of ground water prospects.

\subsubsection{Residual Hills}

Tone is light greyish to greenish for rock exposures. Coarse texture, shape and size-irregular and rounded with radial drainage. Drainage is radial. It is found in SB-II and SB-V covering a total area of $3.76 \mathrm{~km}^{2}$. Maximum coverage is found in SB-V (1.94\%). Thus, the ground water in this unit is very poor to poor, it acts as run off zone.

\subsection{Land Use/Land Cover Analysis}

The study area comprises land use/land cover categories such as agricultural land, uncultivated land, open forest, open scrub, wasteland, waterbody, settlement, ravenous land with and without scrub and exposed rock and wasteland (quarry) (Figure 6(a), Figure 6(b)). 3 bands in IRS P6 LISS-III data were utilized for making False Colour Composite (FCC) which allows vegetation to appears in red, Clear water appears dark-bluish, settlement appeared as blue whereas, waterbody as dark tone. Agricultural land is recognized on FCC by its yellowish tone, smooth texture, regular to sub-regular boundary outlines and contiguous pattern. It covers an area of about 67.49 $\mathrm{km}^{2}$. Open forest is delineated on the image by its reddish tone, coarse texture, contiguous to non-contiguous pattern and association with relatively low to moderate relief zones, with an area of $1.57 \mathrm{~km}^{2}$. Open scrub covers an area of $101.48 \mathrm{~km}^{2}$ and is identified by its pinkish to light yellow tone, irregular boundary outline, rough texture and association with relatively plain areas. Wasteland normally exhibits light tone because of high reflectance, it shows irregular pattern with smooth texture and sharp boundary outline, absence of any land use activity with area of about $35.86 \mathrm{~km}^{2}$. Water bodies appear dark on satellite data due to absorption of incoming IR radiation in the near infrared region, hence they are recognized by dark tone, smooth texture, well defined boundary outline and sharp contact with other land uses. It covers an area of $0.53 \mathrm{~km}^{2}$. Built-up land or settlement is characterized by bluish tone with irregular shape, near circular boundary outline and sharp contact with adjacent land use and association with roads and highways. The barren/exposed rock area is around $28.20 \mathrm{~km}^{2}$ and is identified by its greenish to brownish tone, rough texture, moderate to high relief and occurs as isolated hillocks and plateau.

\subsection{GIS Analysis}

GIS is an efficient tool to integrate different layers to determine inter-relationship amongst the various themes 


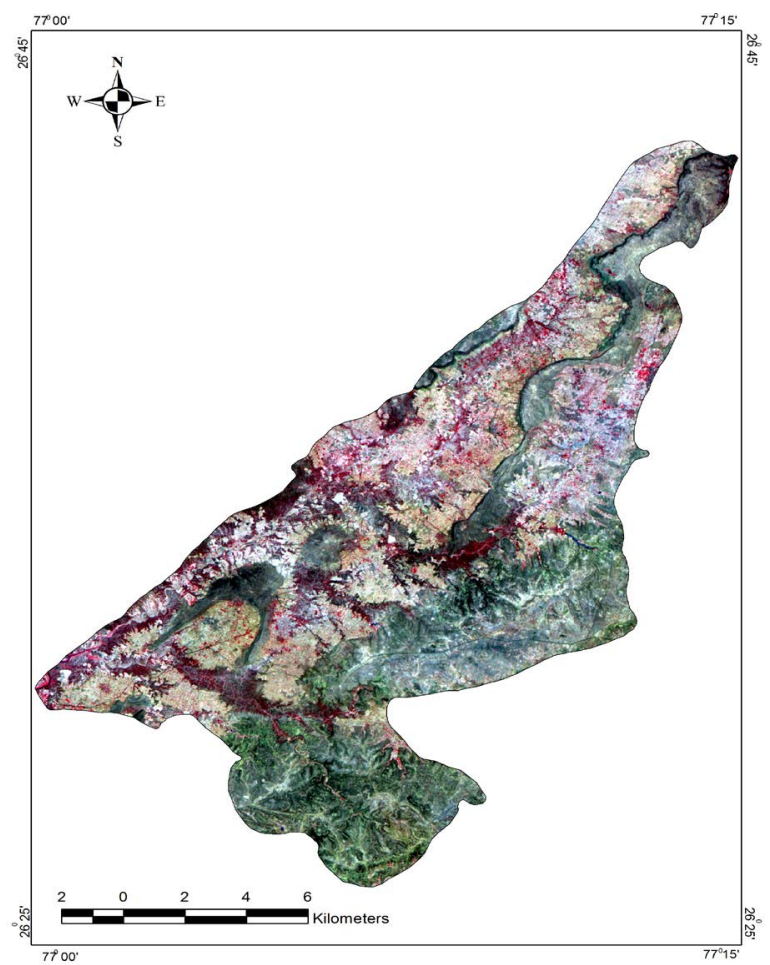

(a)

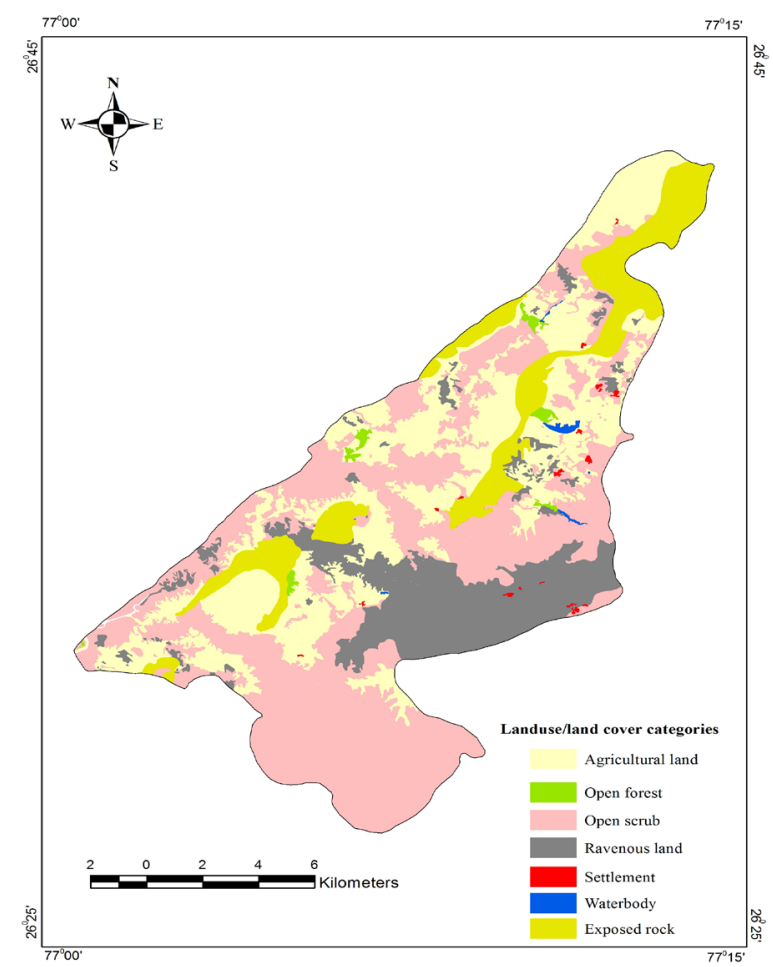

(b)

Figure 6. (a) IRS P6 LISS-III satellite image; (b) Land use/land cover map derived from IRS P6 data.

in water resource development plan. Different thematic layers are brought to a common coordinate system so that integration is possible and accuracy of the output is maintained. Drainage, hydrogeomorphology and slope map were superimpose to discern ground water potential zones. Whereas, overlay analysis of drainage, slope, land use/land cover, litho and hydrogeomorphic units in a GIS domain proved out to be very helpful for site selection and construction of artificial recharge structures within the Manchi basin (Figure 7). Table 5 provides the results of the integration of various themes to formulate a water resource development plan in the Manchi basin.

\section{Conclusions}

Remote sensing and GIS have demonstrated their capability in framing water resource development plan and management strategies in Manchi basin. This integrated approach proved to be useful for selecting suitable sites of ground water deficit areas which requires immediate measures to tap rainwater.

High values of bifurcation ratios for sub-basins I, IV, V suggests that either check dam or nala bund may be planned due to low soil permeability and high erosion rate. Whereas, low elongation ratio suggests for a check dam. Lower value of ruggedness suggests percolation tanks. Drainage map was superimposed on land use/land cover map to identify suitable sites for constructing water harvesting conservation structures so as to protect the natural resources of Manchi basin. In SB-I percolation tank, nala bund and check dam may be constructed on 1st, 2nd and 3rd orders where the land use present is ravenous land (OS), uncultivated land and open forest. In SB-II nala bund and check dam are suggested on 1st and 2nd order with ravenous land (OS), uncultivated land as land use. SB-III check dam, percolation tank were proposed with ravenous land (OS), uncultivated land and exposed rock as land use on 1st or 2nd order. Whereas in SB-IV Percolation tank, nala bund, check dam were proposed with exposed rock, ravenous land (OS), uncultivated land on 1st or 2nd. Lastly in SB-V nala bund, check dam with land use open scrub, ravenous land, uncultivated land on 2nd or 3rd were proposed. Thus, the proposed water harvesting structures construction in future time will lead to the improvement of groundwater conditions and conservation of the natural resources within the basin area. The results of the study may be utilized by the district and local authorities in development of the Manchi basin as a whole, where water may be taken as the central theme. 


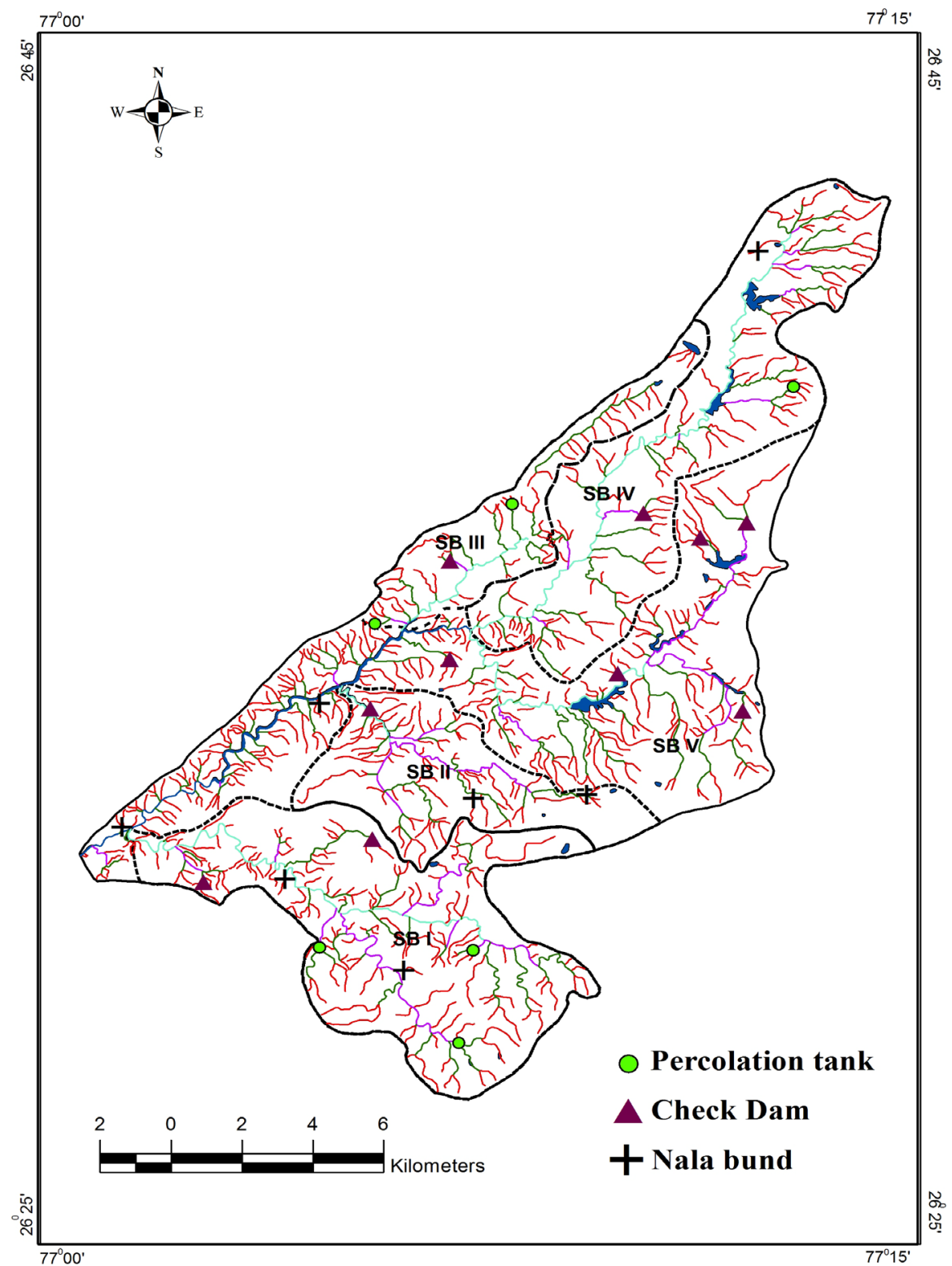

Figure 7. Locations of proposed structure.

Table 5. Site selection criteria for proposed structures.

\begin{tabular}{|c|c|c|c|}
\hline Sub basin & Proposed structure & Land use & Drainage order \\
\hline $\mathbf{I}$ & Percolation tank, nala bund, check dam & $\begin{array}{l}\text { Ravenous land (open scrub), uncultivated land, } \\
\text { open forest }\end{array}$ & 1st, 2nd or 3rd \\
\hline II & Nala bund, check dam & $\begin{array}{l}\text { Ravenous land (open scrub), uncultivated land, } \\
\text { ravenous land }\end{array}$ & 1st or 2 nd \\
\hline III & Check dam, percolation tank & $\begin{array}{l}\text { Ravenous land (open scrub), uncultivated land, } \\
\text { exposed rock }\end{array}$ & 1st or 2nd \\
\hline IV & Percolation tank, nala bund, check dam & $\begin{array}{l}\text { Exposed rock, ravenous land (open scrub), } \\
\text { uncultivated land }\end{array}$ & 1st or 2nd \\
\hline $\mathbf{V}$ & Nala bund, check dam & Open scrub, ravenous land, uncultivated land & 2nd or 3rd \\
\hline
\end{tabular}




\section{Acknowledgements}

The first author acknowledges the financial support received from University Grants Commission (UGC), in the form of Maulana Azad National Fellowship. Thanks are also due to the Chairman, Department of Geology, A.M.U, Aligarh for providing necessary infrastructure facilities. Sincere thanks to National Remote Sensing Centre, Hyderabad, for providing satellite data, IMD, Pune for climate data and ASTER website for elevation data.

\section{References}

[1] Obi Reddy, G.P., et al. (2004) Drainage Morphometry and Its Influence on Landform Characteristics in a Basaltic Terrain, Central India: A Remote Sensing and GIS Approach. International Journal of Applied Earth Observation and Geoinformation, 6, 1-16. http://dx.doi.org/10.1016/j.jag.2004.06.003

[2] Rao, S. (2009) A Numerical Scheme for Groundwater Development in a Watershed Basin of Basement Terrain: A Case Study from India. Hydrogeology Journal, 17, 379-396. http://dx.doi.org/10.1007/s10040-008-0402-2

[3] Strahler, A.N. (1964) Quantitative Geomorphology of Drainage Basins and Channel Networks. In: Chow, V.T., Ed., Handbook of Applied Hydrology, McGraw Hill, New York, 39-76.

[4] Khan, M.A., et al. (2006) Prospecting Ground Water Resources Using RS-GIS-A Case Study from Arid Western Rajasthan of India. Journal of the Indian Society of Remote Sensing, 34, 171-179. http://dx.doi.org/10.1007/BF02991822

[5] Rao, Y.S. and Jugran, D.K. (2003) Delineation of Groundwater Potential Zones and Zones of Groundwater Quality Suitable for Domestic Purposes Using Remote Sensing and GIS. Hydrological Sciences-Journal-des Sciences Hydrologiques, 48, 821-833. http://dx.doi.org/10.1623/hysj.48.5.821.51452

[6] Mondal, N.C., et al. (2008) Integrated Approach for Identification of Potential Groundwater Zones in Seethanagaram Mandal of Vizianagaram District, Andhra Pradesh, India. Journal of Earth System Science, 117, 133-144. http://dx.doi.org/10.1007/s12040-008-0004-3

[7] Javed, A. and Wani, M.H. (2009) Delineation of Groundwater Potential Zones in Kakund Watershed, Eastern Rajasthan, Using Remote Sensing and GIS Techniques. Journal Geological Society of India, 73, 229-236. http://dx.doi.org/10.1007/s12594-009-0079-8

[8] Kushwaha, S.P.S., et al. (2010) Sustainable Development Planning in Pathri Rao Sub-Watershed Using Geospatial Techniques. Current Science, 98, 1479-1486.

[9] Saraf, A.K. and Choudhury, P.R. (1998) Integrated Remote Sensing and GIS for Groundwater Exploration and Identification of Artificial Recharge Sites. International Journal of Remote Sensing, 19, 1825-1841. http://dx.doi.org/10.1080/014311698215018

[10] Ghayoumian, J., Ghermezcheshme, B., Feiznia, S. and Noroozi, A.A. (2005) Integrating GIS and DSS for Identification of Suitable Areas for Artificial Recharge, Case Study, Meimeh Basin, Isfahan, Iran. Environmental Geology, 47, 493-500. http://dx.doi.org/10.1007/s00254-004-1169-y

[11] Ravi Shankar, M.N. and Mohan, G. (2005) Assessment of the Groundwater Potential and Quality in Bhatsa and Kalu River Basins of Thane District, Western Deccan Volcanic Province of India. Environmental Geology, 49, 990-998. http://dx.doi.org/10.1007/s00254-005-0137-5

[12] Ramakrishnan, D., Bandyopadhyay, A. and Kusuma, K.N. (2009) SCS-CN and GIS-Based Approach for Identifying Potential Water Harvesting Sites in the Kali Watershed, Mahi River Basin, India. Journal of Earth System Science, 118, 355-368. http://dx.doi.org/10.1007/s12040-009-0034-5

[13] Clarke, J.J. (1966) Morphometry from Maps, Essays in Geomorphology. Elsevier Publishing Company, New York, 235-274.

[14] Javed, A., Khanday, M.Y. and Rais, S. (2011) Watershed Prioritization Using Morphometric and Land Use/Land Cover Parameters: A Remote Sensing and GIS Based Approach. Journal Geological Society of India, 78, 63-75. http://dx.doi.org/10.1007/s12594-011-0068-6

[15] Schumm, S.A. (1956) Evolution of Drainage Systems and Slopes in Badlands at Perth Amboy, New Jersey. Geological Society of America Bulletin, 67, 597-646. http://dx.doi.org/10.1130/0016-7606(1956)67[597:EODSAS]2.0.CO;2

[16] Horton, R.E. (1932) Drainage Basin Characteristics. Transactions of the American Geophysical Union, 13, $350-361$. http://dx.doi.org/10.1029/TR013i001p00350

[17] Horton, R.E. (1945) Erosional Development of Streams and Their Drainage Basins: Hydrophysical Approach to Quantitative Morphology. Geological Society of American Bulletin, 56, 275-370. http://dx.doi.org/10.1130/0016-7606(1945)56[275:EDOSAT]2.0.CO;2

[18] Miller, V.C. (1953) A Quantitative Geomorphic Study of Drainage Basin Characteristics in the Clinch Mountain Area. 
New York. Columbia University, Virginia and Tennessee, Proj. NR, Technical Report, 389-402.

[19] Manu, M.S. and Anirudhan, S. (2008) Drainage Characteristics of Achankovil River Basin, Kerala. Journal of Geological Society of India, 71, 841-850.

[20] Gottschalk, L.C. (1964) Reservoir Sedimentation. In: Chow, V.T., Ed., Handbook of Applied Hydrology, McGraw Hill Book Company, New York.

[21] Sreedevi, P.D., Subrahmanyam, K. and Ahmed, S. (2005) The Significance of Morphometric Analysis for Obtaining Groundwater Potential Zones in a Structurally Controlled Terrain. Environmental Geology, 47, 412-420. http://dx.doi.org/10.1007/s00254-004-1166-1

[22] Gorokhovich, Y. and Voustianiouk, A. (2006) Accuracy Assessment of the Processed SRTM-Based Elevation Data by CGIAR Using Field Data from USA and Thailand and Its Relation to the Terrain Characteristics. Remote Sensing of Environment, 104, 409-415. http://dx.doi.org/10.1016/j.rse.2006.05.012 